„Przekłady Literatur Słowiańskich”. T. 11, cz. 1, s. 1-23

ISSN 2353-9763 (wersja elektroniczna)

DOI https://doi.org/10.31261/PLS.2021.11.01.02

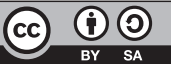

\title{
Modernistyczna obsceniczność w przekładzie: ukraińskie i rosyjskie tłumaczenia Kochanka Lady Chatterley D.H. Lawrence'a u schyłku ZSRR
}

\author{
Modernist Obscenity in Translation: \\ Ukrainian and Russian Translations of \\ Lady Chatterley's Lover by D. H. Lawrence \\ in the Late USSR
}

\author{
Andrij Saweneć \\ iD https://orcid.org/0000-0003-2378-3688 \\ THE JOHN PAUL II CATHOLIC UNIVERSITY OF LUBLIN \\ sawenec@kul.pl
}

Data zgłoszenia: 8.12.2020 r. ～Data akceptacji: 17.02.2021 r.

\begin{abstract}
The paper focuses on Ukrainian and Russian translations of Lady Chatterley's Lover by D. H. Lawrence, published in 1989 and 1990. The framework for the analysis is provided by Loren Glass's idea of a significant role of obscene vocabulary in the aesthetics of the twentieth-century Anglo-American literary modernism. The comparison of the two translations shows significant differences in the translators' approaches to rendering Lawrence's sexual-based language.
\end{abstract}

KEYWORDS | D. H. Lawrence, modernism, obscenity, taboo, translation 


\section{Wstęp \\ Kochanek Lady Chatterley jako przedmiot tłumaczenia}

U schyłku istnienia ZSRR na łamach czasopism poświęconych literaturze obcej - wydawanego w Kijowie miesięcznika „Wseswit” i wychodzącego w Moskwie miesięcznika „Inostrannaja litieratura” — w odstępie kilku miesięcy ukazały się dwa tłumaczenia powieści Davida Herberta Lawrence’a Kochanek Lady Chatterley na język ukraiński (tłum. Sołomija Pawłyczko) ${ }^{1}$ i rosyjski (tłum. Marina Litwinowa oraz Igor Bagrow $)^{2}$. Przekłady te można zaliczyć do najbardziej zauważalnych prób przyswojenia dziedzictwa angielskojęzycznego modernizmu przez literaturę ukraińską i rosyjską u schyłku ZSRR, a więc w okresie liberalizacji politycznej, gospodarczej i obyczajowej oraz upadania aparatu cenzury. Będąc elementem szerszego procesu „nadrabiania zaległości” w zakresie recepcji dziedzictwa XX-wiecznego modernizmu literackiego na obszarze radzieckim, publikacje te wpisywały się jednocześnie w tendencje do przekraczania granicy tabu obyczajowego i językowego ${ }^{3}$ zaobserwowane na rynku prasy i literatury popularnej w ostatnich latach istnienia ZSRR. Zatem logicznie byłoby założyć, że po około 60 latach od ukazania się powieści i po prawie 30 latach od jej pierwszej nieocenzurowanej publikacji w Wielkiej Brytanii w całkiem odmiennym kontekście społeczno-politycznym powieść Lawrence’a przyczyniała się do zmiany powszechnych wyobrażeń na temat granic wolności w literaturze - zarówno ze względu na treść powieści, jak i na samą warstwę słowną.

Spojrzenie teraz, po 30 latach, na publikacje przybliżające jedno z centralnych dzieł modernizmu angielskiego dwóm największym pod kątem liczby użytkowników języka grupom czytelników w ZSRR prowokuje szereg pytań. W przypadku tłumaczenia utworu o tak subwersywnym ładunku estetycznym $\mathrm{z}$ perspektywy norm panujących w docelowym polisystemie literackim warto stawiać pytania o holistyczność i bezkompromisowość podejść różnych tłuma-

1 D.G. Lourens, 1989-1990: Kohanec' ledì Čatterlej. S. Pavličko, per. „Vsesvìt”, nr 12 (1989), s. 2-46; nr 1 (1990), s. 56-129; nr 2 (1990), s. 72-121.

2 D.G. Lourens, 1990: Lûbovnik ledi Čatterli. I. Bagrov, M. Litvinova, per. „Inostrannâa literatura", nr 9, s. 5-72; nr 10, s. 58-125; nr 11, s. 128-185.

3 Według definicji A. Skudrzykowej i K. Urban tabu językowe to „wyrazy i wyrażenia, których w danej społeczności nie można lub nie wypada publicznie używać, ponieważ ich użycie naruszy reguły kulturowe w tej społeczności obowiązujące”. W przypadku powieści Lawrence’a mowa przede wszystkim o „tabu z powodu przyzwoitości, skromności i wstydu", które obejmuje nazwy części ciała i nazwy dotyczące sfery erotyki. Zob. A. Skudrzykowa, K. Urban, 2000: Mały słownik terminów z zakresu socjolingwistyki i pragmatyki językowej. Kraków, Towarzystwo Miłośników Języka Polskiego-Warszawa, Spółka Wydawniczo-Księgarska, s. 142.

\begin{tabular}{l|l} 
PLS.2021.11.01.02 & s. 2 z 23
\end{tabular} 
czy osadzonych przecież w kontekście kilkudziesięcioletniej tradycji „radzieckiej szkoły przekładu". Nie bez znaczenia będą tutaj kwestie indywidualnej wrażliwości estetycznej tłumaczy, ich habitusu, chociaż nie można zapominać o tym, że tłumacz pozostaje tylko jednym $\mathrm{z}$ ogniw procesu wydawniczego o ograniczonej mocy decyzyjnej.

Niniejszy artykuł stanowi próbę prześledzenia jednego tylko aspektu językowego stanowiącego charakterystyczny wymiar powieści Lawrence’a, a mianowicie przekroczenia tabu językowego. Ma również na celu ustalenie tego, jak ten aspekt został oddany w pierwszych rozpowszechnionych tłumaczeniach powieści na języki ukraiński i rosyjski. Żeby osadzić wyniki analizy porównawczej przekładów w szerszym kontekście, ich opis będzie poprzedzony omówieniem wątku „obsceniczności” powieści na tle estetyki modernizmu i ogólnymi uwagami na temat recepcji literatury modernizmu w ZSRR oraz tradycji przekładu funkcjonującej w uwzględnionych kulturach docelowych.

\section{„Obsceniczność" powieści Lawrence’a w kontekście estetyki modernizmu}

Przyjmując za pewnik zasadniczą przynależność twórczości Lawrence’a do paradygmatu modernizmu ${ }^{4}$, jakkolwiek różne definicje i wyznaczniki można stosować wobec tego ogółu praktyk estetycznych ${ }^{5}$, warto zgodzić się także ze stwierdzeniem, że w literaturze spod znaku modernizmu doniosłą rolę odgrywała problematyka ciała i cielesności. Amerykański badacz Loren Glass zaobserwował wręcz liczne podobieństwa między modernizmem a pornografią w twórczości od Gustave’a Flauberta do Williama S. Burroughsa: tak jedno, jak i drugie bowiem „skupiało się na subwersywnej reprezentacji cielesności i dewiacji - głównie kobiecej seksualności i seksualnej autonomii - kwestionujących burżuazyjne protokoły moralne" ${ }^{\prime \prime}$. Zdaniem Glassa, doniosłą rolę w estetyce XX-wiecznego angielsko-amerykańskiego modernizmu literackiego odgrywały wyrazy obsceniczne:

4 Zob. np. M. Bell, 2001: Lawrence and modernism. W: A. Ferninogh, ed.: The Cambridge Companion to D. H. Lawrence. Cambridge, New York, Cambridge University Press, s. 179-196.

5 Zob. np. E. Możejko, 1994: Modernizm literacki: niejasność terminu i dychotomia kierunku. „Teksty Drugie”, nr 5-6, s. 26-45.

6 L. D. Glass, 2006: Redeeming Value: Obscenity and Anglo-American Modernism. „Critical Inquiry", t. 32, nr 2, s. 348. 
liczni dwudziestowieczni pisarze angielskojęzyczni, głównie mężczyźni, od Jamesa Joyce’a do Williama Burroughsa, przywiązywali dużą wagę do tej garstki słów, obstając przy ich integralnym znaczeniu dla swych projektów literackich. W licznych procesach sądowych i kontrowersjach będących wynikiem tych obstawań słowa te zaczęły z kolei odgrywać centralną rolę w debacie publicznej na temat natury i znaczenia modernizmu literackiego w świecie angielsko-amerykańskim ${ }^{7}$.

Rzeczywiście, do podjęcia tematu obecności wyrazów obscenicznych w sztuce słowa w dużym stopniu przyczyniła się seria skandali obyczajowych inspirowanych przez dzieła literackie, a w wielu przypadkach także procesy sądowe, które w ciągu stuleci oddziaływały na kształtowanie się wyobrażeń o granicach dozwolonego w dyskursie publicznym. Najdobitniej jednak temat ten uwidocznił się w kontekście recepcji utworów zaliczanych do modernizmu ${ }^{8}$. Przekraczanie tabu językowego i obyczajowego przez autorów tworzących w tym paradygmacie współgra z kategorią szoku wymienianą w literaturze jako jedna z cech charakteryzujących modernistyczne praktyki artystyczne. Shefali Mehta twierdzi, że we wszystkich ruchach spod znaku modernistycznych „-izmów” da się zauważyć chęć zaszokowania czytelnika lub widza ${ }^{9}$. Dowartościowanie estetyczne szoku, zdaniem Williama Solomona, „należy do zestawu XX-wiecznych, głównie modernistycznych prób konceptualizacji sztuki jako emocjonalnie naładowanej, niesłychanie intensywnej praktyki kulturowej”" ${ }^{\prime 0}$. Jeżeli chodzi o modernistyczną praktykę używania wyrazów obscenicznych, jej ogólny cel można sformułować jako rzucanie wyzwania utartym, zakłamanym schematom rządzącym obyczajowością społeczeństwa. Sięgnięcie po te wyrazy stawało się gestem, którego celem było zaszokowanie, wymierzenie „policzka gustom publiczności”, by posłużyć się tytułem almanachu i manifestu rosyjskiej awangardowej grupy Hylaea ${ }^{11}$.

7 L. D. Glass, 2007: \#\$\%^ぬ*!?: Modernism and Dirty Words. „Modernism/Modernity”, t. 14, nr 2, s. 210. Tu i dalej tłumaczenia cytatów niepochodzących z literatury podmiotowej mojego autorstwa - A.S.

8 Wątki te zgłębiają m.in.: E. De Grazia, 1992: Girls Lean Back Everywhere. New York, Random House; A. Parkes, 1996: Modernism and the Theatre of Censorship. New York, Oxford University Press; A. Pease, 2000: Modernism, Mass Culture, and the Aesthetics of Obscenity. Cambridge, Cambridge University Press.

9 S. Mehta, 2016: Literary Modes of Modernism: Aesthetic Styles as Reflection of Philosophical Worldview. „Spring Magazine on English Literature”, t. 2, nr 1, s. 7.

10 W. Solomon, 2017: On Shock Therapy: Modernist Aesthetics and American Underground Film. „Screen Bodies”, t. 2, nr 1, s. 75.

11 Co ciekawe, tak właśnie - jako „policzek hipokryzji i dewocji Anglosasów” - odebrała powieść Kochanek Lady Chatterley jej pierwsza tłumaczka na język rosyjski Tatiana Leszczenko. Zob. T. Leŝenko, 1991: Dolgoe buduŝee: Vospominaniâ. Moskva, Sovetskij pisatel', s. 8. 
Byłoby uproszczeniem sprowadzić do tego celu gest estetyczny poczyniony przez autora powieści o lady Chatterley. Obecność wyrazów uznawanych w języku angielskim za obsceniczne Lawrence uzasadnił w eseju A propos Kochanka Lady Chatterley. Jako że całej książce przyświecał cel, „by mężczyźni i kobiety byli zdolni do myślenia o seksie w sposób gruntowny, pełny, uczciwy i czysty" ${ }^{12}$, jedną z intencji autora stało się swoiste "oczyszczenie” wyrazów dotyczących sfery płci z nawarstwień utrwalonych w konwencji społecznej. Zdaniem Lawrence’a, moc ekspresyjna wyrazów uważanych za obsceniczne

miała stanowić duże niebezpieczeństwo dla obskurnej, brutalnej natury Średniowiecza i być może wciąż jest zbyt potężna dla ograniczonych, nie do końca przebudzonych osobowości dzisiaj. Prawdziwa kultura nakazuje nam jednak przywiązywać do jakiegoś słowa tylko te reakcje mentalne i wyobrażeniowe, które należą do umysłu, i chroni nas przed gwałtownymi i bezkrytycznymi reakcjami fizycznymi mogącymi urągać przyzwoitości. W przeszłości umysł ludzki był zbyt słaby lub zbyt nieokrzesany, by kontemplować własne reakcje fizyczne, które go ogarnęły. To należy już do przeszłości. Kultura i cywilizacja nauczyły nas oddzielać te reakcje od siebie ${ }^{13}$.

Dokładnie w ten sposób odczytał intencje autora literaturoznawca i socjolog Richard Hoggart, który w 1960 roku zeznawał jako ekspert w procesie sądowym dotyczącym powieści Lawrence’a. Zdaniem Hoggarta, w trakcie czytania wyrazy odbierane jako szokujące sukcesywnie „oczyszczały się"14. Jakkolwiek szczytne intencje przyświecały Lawrence’owi, wprowadzenie przez niego na karty powieści tzw. słów czteroliterowych w ramach realizacji programu „uwolnienia, ucywilizowania umysłu” ${ }^{\prime 15}$ mogło wywołać szokujący efekt ze względu na to, kto je wypowiada. W kontekście uściślenia dotyczącego płci mówców w cytowanej wypowiedzi Glassa („głównie mężczyźni”) warto zwrócić uwagę na szokotwórczy potencjał sytuacji ukazanej w rozdziale XII omawianej powieści, kiedy Constance dopytuje Mellorsa o znaczenie słowa cunt, błędnie utożsamiając je ze słowem fuck.

Zgodnie z tradycyjnym przekonaniem, w społeczeństwie brytyjskim panuje dużo większe przyzwolenie na używanie wyrazów ze sfery tabu przez mężczyzn niż przez kobiety ${ }^{16}$, co jest całkiem prawdziwe w odniesieniu do większości społeczeństw, które „wydają się mieć większe oczekiwania względem kobiet

12 D. H. Lawrence, 1981: Lady Chatterley's Lover. London, Heinemann, s. 5.

13 Ibidem.

14 C. H. Rolph, ed., 1961: The Trial of Lady Chatterley. London, Penguin Books, s. 98-99.

15 Por. D. H. Lawrence, 1981: Lady Chatterley's Lover..., s. 6.

16 Zob. P. Trudgill, 2000: Sociolinguistics: An Introduction to Language and Society. 4th ed. London, Penguin Books, s. 69. 
co do przestrzegania norm społecznych"17. Ronald Wardhaugh twierdzi, że „kobiety nie posługują się przekleństwami i bluźnierstwami używanymi przez mężczyzn, a jeśli już, to czynią to w innych okolicznościach i inaczej są za to oceniane" ${ }^{\prime 18}$. Wydaje się zasadne powiązanie tej asymetrii w zachowaniu językowym z „mocą” wyrazów tabu stosowanych jako inwektywy ${ }^{19}$ - mocą określaną jako „maskuliniczna” ${ }^{20}$. Pisarz, redaktor i krytyk Malcolm Cowley przywołany przez prawnika Charlesa Rembara w książce The End of Obscenity (1968) wręcz uznał „pewien zestaw krótkich angielsko-amerykańskich słów na oznaczenie funkcji cielesnych" za część tajnego języka mężczyzn porównywalnego do tajnego języka mężczyzn odkrytego przez antropologów wśród plemion południowego Pacyfiku:

Słów tych używano w palarni, w barze, w męskim zakładzie fryzjerskim, nie miały one jednak być znane dla żadnej kobiety, chyba że była to kobieta zupełnie zdegradowana. Po pierwszej wojnie światowej kobiety coraz dobitniej domagały się dostępu do miejsc będących wcześniej uświęconymi miejscami mężczyzn — do palarni, baru, a nawet do męskiego zakładu fryzjerskiego, i domagały się wiedzy na temat tajnego języka mężczyzn ${ }^{21}$.

Przywłaszczenie języka uważanego za męski stało się więc organicznym elementem procesu społecznej i kulturowej emancypacji kobiet. Zgodnie z obserwacją cytowanego przez Glassa Bernarda de Voto, tolerancja dla jednosylabowych wyrazów obscenicznych, a nawet mniej lub bardziej rutynowe posługiwanie się nimi, zaczęło być w szerokich kręgach wykształconych i dobrze usytuowanych wielkomiejskich kobiet znakiem otwartości, wyrafinowania, wyrozumiałości, towarzyskości, a nawet dowcipu ${ }^{22}$. A zatem, jak obserwuje Karen Stapleton, używanie wulgaryzmów przez kobiety w pewnych kontekstach i w określonych celach staje się - na tle dominujących norm i oczekiwań socjokulturowych - potężnym środkiem wyrażania tożsamości, co też pokazują przywołane przez autorkę badania (podczas gdy wiele prac z zakresu socjolingwistyki, jak zaznacza Stapleton, wciąż bazuje na tradycyjnych wyobrażeniach na ten temat) ${ }^{23}$.

17 Zob. ibidem, s. 73.

18 R. Wardhaugh, 2006: An Introduction to Sociolinguistics. 5th ed. [S.l.], Blackwell Publishing, s. 322.

19 Zob. P. Trudgill, 2000: Sociolinguistics: An Introduction..., s. 19.

20 Zob. L. D. Glass, 2007: \#\$^^^!?: Modernism and Dirty Words..., s. 212.

21 Cyt. za: ibidem, s. 211.

22 Cyt. za: ibidem, s. 213.

23 Zob. K. Stapleton, 2003: Gender and Swearing: A Community Practice. „Women and Language", t. 26, nr 2, s. 22, 23. Wybitnym przykładem kontekstu, w którym zauważalna wulgaryzacja języka kobiet $\mathrm{w}$ dyskursie publicznym zafunkcjonowała jako narzędzie przełamania „męskiej retoryki”, stała się fala protestów społecznych w Polsce pod 
Wątek ten, raczej marginalny w przypadku omawianej powieści Lawrence’a, zyskuje na znaczeniu w sytuacji, gdy instancją odpowiedzialną za przeniesienie powieści do innego kontekstu kulturowego staje się tłumaczka — kobieta.

\section{Kontekst publikacji przekładów powieści Lawrence’a}

W na wskroś zideologizowanym dyskursie nauki o literaturze w ZSRR zachodnia, „burżuazyjna” literatura modernistyczna przyjęła kształt swoistego antykanonu przeciwstawianego kanonowi literatury socrealistycznej ${ }^{24}$. Modernizm postrzegany był jako ogół prądów literackich i artystycznych z przełomu XIX/XX wieku „wyrażających kryzys kultury burżuazyjnej i charakteryzujących się zerwaniem $z$ tradycjami realizmu” ${ }^{25}$ oraz utożsamiany z dekadencją ${ }^{26}$. To właśnie Lawrence został obwołany przez jednego z czołowych krytyków radzieckich, Dmitrija Mirskiego, „głównym artystycznym wyrazicielem tej strony burżuazyjnej dekadencji, która »dąży do prymitywu«", podczas gdy powieść Kochanek Lady Chatterley dostała etykietę "intelektualnej pornografii” ${ }^{27}$. Nic dziwnego zatem, że po kilku latach od ukazania się pierwszych tłumaczeń dzieł Lawrence’a w warunkach względnie pluralistycznej sytuacji w sferze literatury, mniej więcej od połowy lat 30., zaprzestano tłumaczeń i publikacji angielskiego pisarza, którego nazwisko wypadło z obiegu literackiego w ZSRR na kilka dekad ${ }^{28}$.

To właśnie w tym okresie, na początku lat 30., w ZSRR zostały stworzone zręby systemu totalnej kontroli państwa nad wszystkimi sferami działalności naukowej i twórczej. Na fundamentach ideologii marksistowsko-leninowskiej konstytuowała się „radziecka szkoła przekładu” - system norm regulujących praktykę przekładu i refleksję przekładoznawczą, w którym status nadrzędny przypisano między innnymi kategoriom „tłumaczenia twórczego” i „tłumaczenia realistycznego”. Tak pojmowane tłumaczenie, przeciwstawiane wszelkim przejawom „literalizmu”

koniec 2020 roku zorganizowanych przez Strajk Kobiet przeciwko decyzji Trybunału Konstytucyjnego w sprawie aborcji.

24 Zob. A. Volynskaâ, 2017: Modernizm kak sovetskij antikanon: literaturnye debaty 1960-1970-h godov. „Logos”, t. 27, nr 6, s. 173.

25 A. M. Prohorov, red., 1979: Sovetskij ènciklopedičeskij slovar'. Moskva, Sovetskaâ ènciklopediâ, s. 830 .

26 L. I. Timofeev, S. V. Turaev, sost., 1974: Slovar' literaturovedčeskih terminov. Moskva, Prosveŝenie, s. 233.

27 D. Mirskij, 1934: Intellidžentsia. Moskva, Sovetskaâ literatura, s. 70-71.

28 Tymczasem pierwsze tłumaczenie Kochanka Lady Chatterley ukazało się w 1932 roku nakładem rosyjskiego wydawnictwa Petropolis w Berlinie. Dla autorki przekładu, Tatiany Leszczenko, było to pierwsze tłumaczenie literatury pięknej. Do ZSRR przemycane były pojedyncze egzemplarze tego wydania. 
i „formalizmu”, w praktyce często sprowadzało się do „korygowania” w przekładach tych elementów utworów oryginalnych, które nie wpisywały się w system dogmatów ideologii komunistycznej ${ }^{29}$. Tłumacz lub badacz literatury uzbrojony w narzędzia teorii marksistowsko-leninowskiej miał wiedzieć lepiej od autora tłumaczonego lub analizowanego dzieła, co ten autor chciał przekazać czytelnikom. Tak oto na przykład w posłowiu do wydanego w 1970 roku rosyjskiego tłumaczenia Odysei kosmicznej Arthura C. Clarke’a pisarz fantasta Iwan Jefremow poinformował czytelników o usunięciu z tekstu przekładu końcowych rozdziałów powieści jako „niezgodnych z własnym, całkiem naukowym światopoglądem Clarke’a”30. W tym samym 1970 roku nazwisko Lawrence’a wróciło do oficjalnego obiegu literackiego w ZSRR: na łamy prasy literackiej trafiły jego pojedyncze wiersze i opowiadania w nowych rosyjskich przekładach ${ }^{31}$ (przekłady ukraińskie pojawiły się w druku dopiero 13 lat później) ${ }^{32}$.

$\mathrm{Na}$ fali szeroko zakrojonych $\mathrm{w}$ drugiej połowie lat 80 . XX wieku przemian społecznych i gospodarczych w ZSRR, które zyskały miano pierestrojki, w sferze wydawniczej postępowała liberalizacja, prowadząca ostatecznie do zniesienia instytucji cenzury. W tym okresie obserwuje się kolejny szczyt popularności tzw. grubych czasopism - miesięczników literackich, które osiągały milionowe nakłady. Czasopisma te nie tylko odgrywały doniosłą rolę w kształtowaniu żywego procesu literackiego, lecz także wypełniały luki, przybliżając spragnionej rzeszy czytelników dzieła autorów przemilczanych, zakazanych, wymazanych $\mathrm{z}$ historii literatury. W sferze publikacji przekładów $\mathrm{z}$ literatury powszechnej do najbardziej poczytnych tytułów należały „Inostrannaja litieratura” w Moskwie oraz „Wseswit” w Kijowie. Właśnie w takim kontekście doszło do pierwszych prób przełamania tabu także w sferze językowej. Rosyjski pisarz Michaił Wieller utrzymuje, że jako pracownik redakcji wydawanego w Tallinnie miesięcznika literackiego „Raduga” odpowiedzialny za publikację fragmentu powieści

29 Szerzej na ten temat zob. S. Witt, 2013: Arts of Accommodation: The First All-Union Conference of Translators, Moscow, 1936, and the Ideologisation of Norms. W: L. Burnett, E. Lego, eds.: The Art of Accommodation. Literary Translation in Russia. Bern, Peter Lang AG, s. 141-184; G. Dmitrienko, 2019: Redefining Translation Spaces in the Soviet Union: FromRevisionist Policies to a Conformist Translation Theory. „Traduction, terminologie, rédaction", t. 32, nr 1, s. 205-229.

30 Cyt. za: T. Gorâeva, 2009: Političeskaâ cenzura v SSSR. 1917-1991 gg. Moskva, Rossijskaâ političeskaâ ènciklopediâ, s. 363.

31 Zob. N. Reinhold, 2007: Russian Culture and the Work of D. H. Lawrence: An Eighty-year Long Appropriation. W: Ch. Jansohn, D. Mehl, eds.: The Reception of D. H. Lawrence in Europe. London, Continuum, s. 190-191.

32 O. Mikitenko, G. Gamalìj, ukl., 2004: Žurnal inozemnoï literaturi „Vsesvit” u XX storičči (1925-2000): Bibliografičnij pokažčik zmistu. Kiïv, Vidavničij dìm „Vsesvit”, s. 30. 
Wasilija Aksionowa Wyspa Krym w zimie 1988 roku $^{33}$ (w rzeczywistości fragmenty powieści Aksionowa opublikowano w numerach 8-10 miesięcznika w roku 1989) odpowiadał również za pierwsze wykorzystanie wyrazów uznawanych za niecenzuralne w oficjalnym obiegu wydawniczym: „Związek [Sowiecki] pękał, Estonia odpływała w niepodległość, [redaktor] naczelny był jednym z liderów Frontu Ludowego, nikt niczego już się nie bał, wyprzedzając o pół roku rosyjskie wydarzenia [...]: przekleństwa były wolnością, rewanżem, figą"34. Rzeczywiście, pod względem wyobrażeń na temat ram dozwolonego w wypowiedziach pisarzy i tłumaczy prowincja wyprzedzała centrum być może nawet o więcej niż pół roku: kiedy latem 1990 roku „Inostrannaja litieratura” wydrukowała tłumaczenie Zwrotnika Raka Henry’ego Millera wykonane w 1962 roku na emigracji przez Gieorgija Jegorowa, wyrazy obsceniczne zostały w nim wykropkowane.

A zatem w okresie, kiedy w nieoficjalnym obiegu wydawniczym zaczęły już na potęgę ukazywać się wątpliwej jakości publikacje o tematyce erotycznej, zaś instytucja cenzury powoli upadała, poczytne czasopisma literackie najpierw w Kijowie, a potem w Moskwie opublikowały skandaliczną powieść Lawrence’a, wywołując zrozumiałe podniecenie, ale też reakcje mniej entuzjastyczne. Na przykład znany tłumacz i krytyk rosyjski Wiktor Toporow w recenzji z 1992 roku dość chłodno potraktował omawianą powieść Lawrence’a, jakość jej tłumaczenia, a wręcz sam fakt dokonania nowego przekładu na język rosyjski i jego publikacji w czasopiśmie (ocenianej przez krytyka jako „chwyt komercyjny”, mało uzasadniony zwłaszcza w obliczu wznowienia przedwojennego tłumaczenia Leszczenko przez wydawców prywatnych) ${ }^{35}$. Ponadto za jeden z mankamentów publikacji Kochanka... Toporow uważał brak odpowiedniej obudowy paratekstualnej. Gwoli sprawiedliwości należy zaznaczyć, że w rzeczywistości redakcje obu czasopism na różne sposoby przygotowywały grunt pod recepcję powieści: w sierpniowym numerze z 1989 roku redakcja „Wseswitu” umieściła przekład głęboko apologetycznego tekstu Aleja Carpentiera Kochanek Lady Chatterley i zapowiedziała na sąsiedniej stronie rozpoczęcie publikacji samej powieści w grudniowym numerze czasopisma (co miało oczywiście stymulować czytelników do prenumeraty na następny rok). Szczególnie dobitnie miało zabrzmieć w odbiorze napisane w 1932 roku zdanie: „Teraz bowiem wiemy, że takich rzeczy nie cierpią urzędnicy, którzy potraktowali jako swój obowiązek strzeżenie naszej moralności!”36. Publikacje poświęcone

33 M. Veller, 2007: NE Nožik NE Sereži NE Dovlatova. Moskva, Izdatel’stvo „AST”, s. 13.

34 Ibidem, s. 14.

35 V. Toporov, 2020: Zapretnyj plod slaŝe. W: Idem: O zapadnoj literature. [S.1.], „Izdatel'stvo K. Tublina”, s. 112.

36 A. Karpentềr, 1989: „Kohanec' ledi Čatterlej”, per. z ìsp. „Vsesvit”, nr 8, s. 102. 
Lawrence’owi i mające na celu właściwie ukierunkować odbiór Kochanka Lady Chatterley wydrukowano także w numerach czasopisma z tłumaczeniem powieści $^{37}$. Z kolei „Inostrannaja litieratura” w numerze 5 z 1989 roku opublikowała trzy eseje pod hasłem „Temat do dyskusji: erotyka i literatura”, w tym Pornografie i obsceniczność samego Lawrence’a ${ }^{38}$.

Kontekst ukazania się obu przekładów byłby niepełny bez zaprezentowania, chociażby w wielkim skrócie, sylwetek tłumaczy. Autorka ukraińskiej translacji Kochanka..., Sołomija Pawłyczko (1958-1999), z wykształcenia anglistka, była badaczką literatury, tłumaczką z języka angielskiego, publicystką. Stała się czołową postacią całego pokolenia intelektualistów ukraińskich między innymi dzięki przełomowej monografii Dyskurs modernizmu w literaturze ukraińskiej (1997) oraz innym pionierskim pracom $\mathrm{z}$ zakresu teorii literatury i historii feminizmu ukazującym nowe perspektywy metodologiczne dla literaturoznawstwa ukraińskiego. Była córką wybitnego poety i tłumacza Dmytra Pawłyczki, jednego z najjaskrawszych twórców pokolenia tzw. szistdesiatnyków, następnie polityka i dyplomaty, zaś w latach 1971-1978 redaktora naczelnego czasopisma „Wseswit”. Jeżeli chodzi o autorów tłumaczenia na język rosyjski, Marina Litwinowa (1929_ 2020) była badaczką języka i literatury angielskiej przez całą karierę zawodową związaną z Moskiewskim Państwowym Instytutem Pedagogicznym Języków Obcych im. M. Toreza (następnie Moskiewskim Państwowym Uniwersytetem Lingwistycznym). Zasłynęła między innymi jako autorka „Rutland-Baconiańskiej” hipotezy co do autorstwa niektórych dzieł Williama Shakespeare’a oraz jako tłumaczka licznych utworów literatury angielskiej i amerykańskiej. Współautor tłumaczenia Kochanka Lady Chatterley, Igor Bagrow (1946-2016), również anglista z wykształcenia, tłumaczył literaturę piękną od 1975 roku, a przed emigracją do USA prowadził seminarium dla tłumaczy funkcjonujące przy redakcji „Inostrannoj litieratury”. Jak widać, tłumacze rosyjscy, należący do różnych pokoleń, w okresie publikacji obu przekładów byli starsi od tłumaczki ukraińskiej i mogli wykazać się dużo większym dorobkiem tłumaczeniowym.

W następnych latach na terenach postsowieckich publikowane były dziesiątki różnych edycji powieści Lawrence’a. Wersja Bagrowa i Litwinowej w latach 1991-2020 wytrzymała kilkadziesiąt (!) wydań książkowych ${ }^{39}$, niejednokrotnie wznawiano też przekład Leszczenko. Pojawiły się także dwa nowsze

37 İ. Boânovs'ka, 1989: Pošuk pervinnoï sutì žittâ. „Vsesvit”, nr 12, s. 4-5; B.-İ. Antonič, 1990: Mistec' pristrasti. „Vsesvit”, nr 2, s. 133.

38 D. G. Lourens, 1989: Pornografiâ i nepristojnosti. U. Komov, per. „Inostrannaâ literatura", nr 5, s. 232-236.

39 Podczas przeszukiwania katalogu elektronicznego Rosyjskiej Biblioteki Państwowej (https://www.rsl.ru/) znaleziono 43 różne edycje książkowe zawierające tłumaczenie I. Bagrowa oraz M. Litwinowej (stan na 29 listopada 2020 roku). 
tłumaczenia, autorstwa Iriny Gul (1991) oraz Walerija Czuchny (2000). W języku ukraińskim oprócz trzech edycji książkowych przekładu Pawłyczko ukazała się wersja Darii Radijenko (2017). Jednak to omawiane w tym artykule tłumaczenia, nawet bez uwzględnienia ich wznowień książkowych, odkryły powieść Lawrence’a dla szerokich rzesz czytelników (w czasie publikacji Kochanka Lady Chatterley nakład „Wseswitu” przekraczał 70 tys. egzemplarzy, podczas gdy nakład „Inostrannoj litieratury” zbliżał się do 330 tys. egzemplarzy) i właśnie one odgrywają rolę kanonicznych w odpowiednich kulturach docelowych.

\section{Obsceniczność w ukraińskim i rosyjskim przekładzie powieści Lawrence’a: studium porównawcze}

Zreferowane w tej części artykułu wybrane spostrzeżenia i konkluzje z porównawczej analizy tekstowej dotyczą jednego tylko wymiaru językowego powieści Kochanek Lady Chatterley, jakim jest obecność w tekście słów odnoszących się do sfery płciowej, w tym wyrazów uznawanych za obsceniczne (ze względu na ograniczenia objętościowe omówienie ogranicza się do trzech jednostek). Sposób potraktowania przez tłumaczy samych tych słów, a ogólniej fragmentów i sytuacji, w których zostały wykorzystane, pozwala na dostrzeżenie istotnych różnic w sposobach rozwiązania tego problemu tłumaczeniowego.

Przykłady zostały zgrupowane w oparciu o wybrane leksemy. Zgromadzony w trakcie badania materiał źródłowy zawiera zestawienie większej liczby leksemów (m.in. cock, balls, arse, shit, piss, bitch), jednak ze względu na ograniczenia objętościowe $\mathrm{w}$ artykule zaprezentowano tylko przykłady użycia wyrazów o największej częstotliwości w powieści Lawrence’a. By pełniej oddać kontekst występowania omawianych leksemów, przytoczono całe zdania lub grupy zdań. Każdy zestaw przykładów zawiera kolejno: tekst oryginału powieści (oznaczony literą a), tekst przekładu Pawłyczko na język ukraiński (oznaczony literą b) i tłumaczenie na język rosyjski Bagrowa i Litwinowej (oznaczony literą c) ${ }^{40}$. W pojedynczych przypadkach sięgnięto także po przekład Leszczenko.

40 Analizowane cytaty z oryginału oraz przekładów ukraińskiego i rosyjskiego przytaczane są odpowiednio za wydaniami: D. H. Lawrence, 1981: Lady Chatterley's Lover...; D. G. Lourens, 1989-1990: Kohanec' ledi Čatterlej...; D. G. Lourens, 1990: Lûbovnik ledi Čatterli... W nawiasach podano numer strony, na której znajduje się cytowany fragment, a w przypadku przekładów - także rocznik i numer czasopisma. 


\section{PENIS}

W cytowanej już recenzji Toporow zwrócił uwagę na to, że w języku rosyjskim terminologia odnosząca się do sfery płciowej wypracowana jest tylko na poziomie medycznym i slangowym, podczas gdy warstwy środkowej brak, na skutek czego tłumacze nie zawsze stają na wysokości zadania ${ }^{41}$. Przykład słowa penis, nienależącego do kategorii wyrazów obscenicznych, pokazuje, że w kwestii nazywania, w wymiarze kognitywnym problemy w tłumaczeniu rosyjskim zaczynają się na poziomie słownictwa neutralnego, „medycznego”. W oryginale wyraz ten pojawia się 22 razy, z czego 6 pierwszych przypadków jego użycia to wypowiedzi jednej z postaci - Tommy'ego Dukesa, kolejne 16 pochodzi z mowy narratora. Tłumaczenie ukraińskie zachowuje prawie każdą bezpośrednią wzmiankę o członku (w pojedynczych przypadkach odpowiednie słowo jest zastąpione metaforycznym określeniem czy zaimkiem osobowym). Dużo poważniejsze zmiany wprowadzono w translacji rosyjskiej. Po adekwatnym pod kątem stylistycznym przetłumaczeniu wypowiedzi Dukesa w pierwszych rozdziałach powieści nazwa członka pojawia się zaledwie jeden raz. W pozostałych przypadkach tłumacze sięgają po techniki eufemizacji, parafrazy bądź tłumaczenia zerowego, co ilustrują przytoczone poniżej przykłady.

Pierwsze dwa zestawy przykładów ukazują wykorzystanie w przekładzie rosyjskim techniki eufemizacji.

(1.1 a) The desire rose again, his penis began to stir like a live bird. (125)

(1.1 b) Знову ожило жадання, його пеніс зашарпався, немов жива пташина. $(1990,1,76)$

(1.1 c) Снова всколыхнулась страсть, птицей встрепенулось его естество. $(1990,10,65)$

(1.2 a) She felt his penis risen against her with silent amazing force and assertion and she let herself go to him. (170)

(1.2 b) Тілом відчула, як його пеніс піднявся з тихою надзвичайною силою й твердістю. $(1990,1,106)$

(1.2 c) Мужская его плоть напряглась сильно, уверенно. $(1990,10,99)$

Jak widać, w przytoczonych fragmentach tłumaczenia na język rosyjski na określenie członka zostały użyte leksemy o znaczeniu 'jestestwo' (1.1 c) i 'męskie ciało' (1.2 c). Ponadto w rosyjskim przekładzie zastosowano inne eufemistyczne wyrazy i wyrażenia oznaczające członek, takie jak мыщuц - „mięsień” (1990, 10, 123; 1990, 11, 137) і таинственный гость — „tajemniczy gość” $(1990,10,99)$.

41 V. Toporov, 2020: Zapretnyj plod slaŝe..., s. 111. 
Kolejne przykłady pokazują wykorzystanie w rosyjskiej translacji techniki parafrazy. W odróżnieniu od eufemizacji, w której następuje zmiana elementu znaczącego przy zachowaniu elementu znaczonego, w tych sparafrazowanych zdaniach zmianie ulega sam element znaczony — zastąpiony przez „ciało” (1.3 c) lub „dół brzucha” (1.4 c).

(1.3 a) He loved the darkness and folded himself into it. It fitted the turgidity of his desire which, in spite of all, was like a riches; the stirring restlessness of his penis, the stirring fire in his loins! (125)

(1.3 b) Він любив темряву і радо поринув у неї. Вона тамувала його жадання, яке, попри все, було немов скарб; хвилюючий неспокій пеніса, хвилюючий вогонь у стегнах! $(1990,1,76)$

(1.3 c) Так приятно укрываться в ночи, прятать переполняющую его страсть, прятать, точно сокровище. И тело его чутко внимало чувству, в паху вновь занимался огонь! $(1990,10,65)$

(1.4 a) She threaded two pink campions in the bush of red-gold hair above his penis. (215)

(1.4 b) Вона поклала два рожеві пуп'янки в кущик червоно-золотистого волосся над його пенісом. $(1990,2,79)$

$(1.4$ c) И Конни воткнула две розовые смолевки в облако золотистых волос внизу его живота. $(1990,11,137)$

W następnych fragmentach rosyjskiego przekładu dokonano radykalnych zmian względem oryginału powieści Lawrence’a (na tle adekwatnego przekładu ukraińskiego), stosując tłumaczenie zerowe, czyli pominięcie poszczególnych jednostek oryginału. Dla porównania w obu zestawach przytoczono odpowiedni fragment wcześniejszego, emigracyjnego przekładu Leszczenko (oznaczony literą d).

(1.5 a) 'And now he's tiny, and soft like a little bud of life!' she said, taking the soft small penis in her hand. 'Isn't he somehow lovely! so on his own, so strange! And so innocent! And he comes so far into me! You must never insult him, you know. He's mine too. He's not only yours. He’s mine! And so lovely and innocent!' And she held the penis soft in her hand. (200-201)

(1.5 b) - А тепер він крихітний і м'який, як маленький пуп'янок життя! - сказала вона, беручи його в руку. - Хіба не красивий! Такий самостійний! Такий дивний! Такий невинний! I так глибоко в мене заходить! Ніколи не ображай його, знаєш. Він і мій так само. Він не тільки твій. Він - мій! Такий милий i невинний! — вона не випускала його з рук. $(1990,1,128)$ 
(1.5 c) - Смотри, какой он маленький и мягкий, Маленький, нераспустившийся бутон жизни. И все равно он красив. Такой независимый, такой странный! И такой невинный. А ведь он был так глубоко во мне. Ты не должен обижать его, ни в коем случае. Он ведь и мой тоже. Не только твой. Он мой, да! Такой невинный, такой красивый, - шептала Конни. (1990, 10, 123)

$(1.5 \mathrm{~d})$ «Теперь он крошечный и мягкий как маленький бутон жизни!» сказала она, беря мягкий маленький пенис в руки. «И какой он прелестный! Такой непонятный и сам по себе! И такой невинный. И он входит так далеко в меня! Ты никогда не должен обижать его - ты знаешь это? Он мой тоже. Он не только твой. Он мой! И такой прелестный и чистый!» И она нежно держала пенис в своей руке ${ }^{42}$.

(1.6 a) 'That's John Thomas's hair, not mine!' he said.

'John Thomas! John Thomas!' and she quickly kissed the soft penis, that was beginning to stir again. 'Ay!' said the man, stretching his body almost painfully. (201)

(1.6 b) - Це не моє волосся, а Джона Томаса, — сказав він.

- Джон Томас! Джон Томас! — і вона швидко поцілувала м’який пеніс, який знову починав надиматися.

- Ай, - сказав чоловік і майже болісно вигнув тіло. $(1990,1,128)$

(1.6 с) - Это шевелюра Джона Томаса, не моя. Эге! - воскликнул мужчина, потянувшись чуть не до боли во всем теле. $(1990,10,123)$

$(1.6 \mathrm{~d})$ «Это волосы Джона Томаса, не не мои», сказал он.

«Джон Томас! Джон Томас!» и она прикоснулась поцелуем к мягкому пенису, который начал подыматься опять. «Ах!» сказал мужчина вытягиваясь ${ }^{43}$.

W przytoczonych przykładach dobitnie widać ingerencję w zarysowaną przez Lawrence’a scenę: czytelnik tłumaczenia Bagrowa i Litwinowej nie dowiaduje się o tym, że Constance bierze członek Mellorsa do ręki ani że następnie go całuje. Skrócenia tekstu dokonano zapewne ze względów pruderyjnych, chociaż nie sposób ustalić, na jakim etapie pracy nad tekstem miała miejsce ingerencja i czy stoi za nią tłumaczka ${ }^{44}$, redaktorzy czy cenzorzy. Faktem jest jednak, że

42 D. Lorens, 1932: Lûbovnik ledi Čatterlej. T. Leŝenko, per. Berlin, Petropolis, s. 263.

43 Ibidem.

44 W publikacji w czasopiśmie „Inostrannaja litieratura” odpowiedzialność tłumaczy nie jest sprecyzowana, natomiast z jednego z późniejszych wydań książkowych można dowiedzieć się, że to M. Litwinowa przetłumaczyła rozdziały XI-XIX powieści, pod- 
żadna z następnych edycji tłumaczenia nie zawierała zmian względem pierwszej publikacji przekładu.

Podsumowując, około jednej trzeciej przypadków użycia wyrazu penis $\mathrm{w}$ powieści Lawrence’a odpowiadają bezpośrednie odniesienia do desygnatu w przekładzie rosyjskim (пенис, половой член). Nieco odmienną sytuację można zaobserwować w odniesieniu do wyrazu phallos/phallus - mimo że w przekładzie rosyjskim nadal stosowano techniki tłumaczenia zerowego lub eufemizacji, proporcja jest inna: w większości przypadków w przekładzie figuruje odpowiednik - фаллос.

\section{CUNT}

W powieści pojawiają się również określenia męskich narządów płciowych uznawane za wulgarne (cock, balls), użyte są one w sytuacjach intymnych, pozbawionych potencjału wulgarności. Bardziej dobitny, a zarazem subwersywny jest przypadek wysoce obscenicznego w języku angielskim rzeczownika cunt oznaczającego kobiece narządy płciowe. W tekście powieści słowo to pojawia się w wypowiedziach postaci kilkanaście razy, w tym najwyraźniej zaznacza się w intymnym dialogu Mellorsa i Constance odgrywającym centralną rolę w Lawrence’owskim programie „rehabilitacji” wyrazów uważanych za obsceniczne.

(2.1 a) 'Th'art good cunt, though, aren't ter? Best bit o' cunt left on earth.

When ter likes! When tha'rt willin'?

'What is cunt?' she said.

'An' doesn't ter know? Cunt! It's thee down theer; an' what I get when I'm i'side thee, and what tha gets when I'm i'side thee; it's a' as it is, all on't'. (173)

(2.1 b) - Ти маєш гарну поцьку, правда! Найкращу на світі. Коли любиш! Коли хочеш!

- Що таке поцька? - запитала вона.

- А ти не знаєш? Це - ти там унизу; те, куди я входжу, куди ти мене пускаєш. Та сама штука. (1990, 1, 109)

(2.1 c) - Кралечка моя. Лучшей кралечки на всем свете нет.

- Что такое кралечка?

- Не знаешь разве? Кралечка - значит любимая баба. (1990, 10, 101)

czas gdy do I. Bagrowa należy przekład rozdziałów I-X. Zob. D. G. Lourens, 2011: Lûbovnik ledi Čatterli. Moskva, Èksmo. 
Przytoczony fragment stawia przed tłumaczem zadanie odnalezienia odpowiednika, który mógłby zabrzmieć autentycznie w intymnej sytuacji. Pawłyczko sięgnęła po istniejącą w ukraińskich gwarach ludowych nazwę żeńskich genitaliów nou,bאa, odnotowaną między innymi w ułożonym na początku XX wieku słowniku Borysa Hrinczenki ${ }^{45}$. Z kolei w tłumaczeniu rosyjskim nastąpiło przesunięcie akcentów. Wypowiedź Mellorsa jest dogłębnie zmieniona: wykorzystany przez niego wyraz кралечкa, będący pieszczotliwą formą pospolitego określenia pięknej kobiety lub ukochanej ${ }^{46}$, oznacza w tej sytuacji samą Constance, nie zaś jej miejsce intymne. Pominięty w tym kontekście desygnat jest przywołany jednak w tłumaczeniu innych wypowiedzi Mellorsa, w których Litwinowa sięgnęła po pieszczotliwe słowo ласонька.

(2.2 a) 'Cunt, that's what tha're after. Tell lady Jane tha wants cunt. John Thomas, an' th' cunt O’ lady Jane! -' (200)

(2.2 b) Поцьки - ось чого ти хочеш! Скажи леді Джейн, що ти хочеш іï, Джоне Томасе, що ти хочеш поцьки леді Джейн! (1990, 1, 127)

(2.2 с) Ласоньку он захотел. Ну, скажи леди Джейн: хочу твою ласоньку. Джон Томас и леди Джейн - чем не пара! $(1990,10,123)$

Na właściwe wyprowadzenie znaczenia wyrazu ласонька przez czytelnika rosyjskiego przekładu pozwala jedynie szerszy kontekst, gdyż samo słowo nie jest odnotowywane w obszernych słownikach języka rosyjskiego ${ }^{47}$.

\section{FUCK}

To czteroliterowe słowo będące jednym z najbardziej rozpoznawalnych wulgaryzmów języka angielskiego i funkcjonujące jako dobitne przekleństwo pojawia się w tekście powieści około 30 razy i jest obarczone różnym ładunkiem, w zależności od sytuacji. Podobnie jak większość wulgaryzmów w języku angielskim, wyraz ten, obok znaczenia pierwotnego, funkcjonuje w wielu znaczeniach pochodnych, służy między innymi do wyrażenia agresji, dezaprobaty, pełni funkcje ekspresywną, impresywną, perswazyjną, ludyczną, fatyczną ${ }^{48}$. Specy-

45 B. D. Grinčenko, 1925: Slovar' ukrainskogo âzyka. Kiïv, Deržavne vidavnictvo Ukraïni, s. 1499. W okresie sowieckim słownik ten nie należał do kanonu leksykograficznego.

46 Por. S. A. Kuznecov, 2000: Bolšoj tolkovyj slovar' russkogo âzyka. Sankt-Peterburg, „Norint", s. 465.

47 W obszernym XIX-wiecznym słowniku Władimira Dala słowo тасонька wiąże się ze znaczeniem 'łakomczuszka', podczas gdy spokrewnione z nim ласица jest odnotowane w znaczeniu 'vulva bestiarum', zob. V. Dal', 1881: Tolkovyj slovar' živago velikoruskago âzyka. Tom' vtoroj. I-O. Sankt-Peterburg, Moskva, Sjemen, s. 251.

48 Por. M. Garcarz, 2006: Wulgaryzmy a przekład, czyli życie wulgaryzmów od oryginału do przekładu. „Acta Universitatis Lodziensis. Linguistica Rossica”, nr 2, s. 162. 
fiką powieści Lawrence’a jest trzymanie się dosłownych, pierwotnych znaczeń omawianych leksemów: ogólnie rzecz biorąc, we wszystkich wystąpieniach wyraz ten jest użyty w znaczeniu dosłownym, jako określenie stosunku płciowego, z tym że w zależności od kontekstu różni się nacechowaniem. W trzech przytoczonych przykładach fuck pojawia się w wypowiedziach odpowiednio: Tommy’ego Dukesa pogardliwie traktującego o współczesnej seksualności (3.1), Constance dopytującej o znaczenie słowa rozpoznanego przez nią jako wulgaryzm (3.2) oraz Mellorsa nieco nonszalancko odwołującego się do własnych relacji intymnych z Constance (3.3).

(3.1 a) Fellows with swaying waists fucking little jazz girls with small boy buttocks, like two collar studs! (59)

(3.1 b) Хлопці, вихляючи стегнами, їбуть, як коні, маленьких джазових дівчат з худими хлоп'ячими задницями ${ }^{49}$. $(1989,12,23)$

(3.1 c) Вихлявые мальчишки спят с грубыми девками, у которых бедра под стать мальчишечьим. $(1990,9,28)$

(3.2 a) 'All on't', she teased. 'Cunt! It's like fuck then.' (173)

(3.2 b) - «Та сама штука», - перекривила вона його. - Тоді це те ж саме, що їбатися. $(1990,1,109)$

(3.2 c) - Кралечка, - опять поддразнила она его. - Это когда спариваются? $(1990,11,101)$

(3.3 a) 'The money is yours, the position is yours, the decisions will lie with you. I'm not just my Lady's fucker, after all.' (256)

(3.3 b) - У тебе гроші, у тебе становище, ти прийматимеш рішення. Зрештою я не просто їбун своєї пані. $(1990,2,107)$

(3.3 c) - У тебя деньги, положение. Решения принимаешь ты. Я не могу делать в жизни только одно - спать с женой. $(1990,11,168)$

Przytoczone przykłady ukazują zasadniczą różnicę w podejściu tłumaczy: Pawłyczko w każdym fragmencie dokonała bezkompromisowego gestu — użyła słów powszechnie uważanych za wysoce nieprzyzwoite, co nawet po upływie 30 lat może razić niektórych czytelników, podczas gdy w rosyjskim tłumaczeniu pojawiły się eufemizmy oznaczające "parzyć się" (3.2 c) oraz „spać z żoną" (3.3 c).

W skali całego ukraińskiego tłumaczenia są to tylko pojedyncze przypadki przekroczenia granicy tabu językowego przez użycie analizowanego leksemu; rosyjscy tłumacze nawet nie spróbowali do tej granicy się zbliżyć. W innych

49 Tłumaczka nie odczytała w sposób właściwy porównania drobnych pośladków do spinek do kołnierzyka (collar studs). 
kontekstach Pawłyczko również zaproponowała bardziej łagodne odpowiedniki słowa fuck - tak się stało na przykład w tłumaczeniu finalnych akapitów powieści, w których słowo to pojawia się kilkakrotnie w tekście listu Mellorsa do Constance. Tłumaczka zapewne uznała, że w kontekście elegijnej, intymnej atmosfery listu użycie wulgaryzmu doprowadziłoby do zbyt daleko idącego dysonansu stylistycznego.

\section{Podsumowanie}

Projekt literacki Lawrence’a odegrał doniosłą rolę w emancypacji pisarstwa i praktyki wydawniczej na obszarze języka angielskiego spod dominacji purytańskich zasad, z pewnością przyczynił się również do zmian w sferze wrażliwości estetycznej i przesuwania granic tabu w licznych innych literaturach, na których języki tłumaczono jego powieści. Dla literatur rosyjskiej i ukraińskiej, w których przypadku proces nadrabiania opóźnień w recepcji zachodniego modernizmu zbiegł się w czasie z demokratyzacją życia społecznego w ramach pierestrojki, publikacja przekładów powieści Lawrence’a stała się swoistym kamieniem milowym na drodze emancypacji estetycznej i językowej społeczeństw postsowieckich. Jednocześnie tłumaczenie powieści stało się wyzwaniem dla tłumaczy i okazją do weryfikacji zasad ukształtowanych w ramach „radzieckiej szkoły tłumaczenia artystycznego" wrogo nastawionej do wszelkich rozwiązań radykalnych i eksperymentatorskich.

Zestawienie wybranych tłumaczeń ukazuje istotne różnice w strategiach przyjętych przez tłumaczy. Pawłyczko postawiła na przełamanie tabu językowego, powtarzając w ten sposób gest samego Lawrence’a i kwestionując utarte tradycje przekładu w kulturze docelowej. Rosyjscy tłumacze zaprezentowali bardziej konwencjonalne i zachowawcze podejście w oddaniu specyfiki warstwy językowej powieści. Oczywiście na ostatecznym kształcie tekstów tłumaczeń zaważyły takie czynniki, jak indywidualna wrażliwość estetyczna i językowa tłumaczy oraz różnice pokoleniowe. Nie sposób teraz ustalić dokładnie, czy za konkretną decyzją translatorską wprowadzającą parafrazę lub tłumaczenie zerowe stali tłumacze, redaktorzy czy też cenzorzy; natomiast można z pewnością stwierdzić, że bardziej śmiałe rozwiązania Pawłyczko były wyłącznie jej własną zasługą. O tym, że tłumaczka musiała przezwyciężyć opór redaktora naczelnego, wspomina znany ukraiński politolog i publicysta Mykoła Riabczuk, który w okresie publikacji powieści pracował w redakcji czasopisma: „był opór ze strony redaktora naczelnego ([Ołeha] Mykytenki) i Sołomija osobiście z nim dyskutowała, przekonywała go, my zaś (redakcja) wspieraliśmy ją i każdy na swój sposób wywierał presję na 
Mykytenkę" ${ }^{\text {"50 }}$. O ostatecznym sukcesie zadecydował, zdaniem Riabczuka, splot kilku czynników:

Sądzę, że decydująca była ogólna atmosfera pieriestrojki (ciągłe poszerzanie granic dozwolonego zachęcające także do swoistej rywalizacji pomiędzy czasopismami: kto pierwszy? kto bardziej zuchwały?), a na to nałożyła się potrójna presja - ta wywierana osobiście przez Sołomiję, presja jej nazwiska oraz presja całej redakcji ${ }^{51}$.

Casus ukraińskiego i rosyjskiego przekładu Kochanka Lady Chatterley współbrzmi z przytoczoną obserwacją Wiellera na temat swoistego opóźnienia centrum wobec prowincji w zakresie emancypacji obyczajowej. Jest to jednak daleko idące uogólnienie: $\mathrm{w}$ warunkach dynamicznych zmian społecznych zbyt dużo zależało od splotów okoliczności i czynników indywidualnych. Nie będzie jednak przesadą stwierdzenie, że ukraiński przekład powieści przygotowywał grunt pod fundamentalne zmiany w nurcie głównym literatury oryginalnej (symbolicznym punktem zwrotnym stała się publikacja powieści Rekreacje Jurija Andruchowycza dwa lata później). Ponadto gest ten, będący symbolicznym wkroczeniem na terytorium „języka mężczyzn”, w sposób naturalny wpisywał się w pionierską działalność Pawłyczko na polu ukraińskich studiów feministycznych. Gorzką ironią jest zatem nie tyle nawet brak należytej refleksji naukowej nad tym przekładem, ile sam fakt pomijania go w bibliografiach przekładów dzieł Lawrence’a ${ }^{52}$, szczególnie zauważalny na tle rzetelnego dokumentowania przez bibliografów przekładów na język rosyjski.

\section{Literatura}

Antonič B.-İ., 1990: Mistec' pristrastì. „Vsesvit”, nr 2, s. 133.

Bell M., 2001: Lawrence and modernism. W: A. Ferninogh, ed.: The Cambridge Companion to D. H. Lawrence. Cambridge, New York, Cambridge University Press, s. 179-196.

Boânovs'ka İ., 1989: Pošuk pervinnoï sutì žittâ. „Vsesvìt”, nr 12, s. 4-5.

50 M. Riabczuk, 2020: Re: Esej. [Wiadomość e-mail do: Andrij Saweneć, 3 kwietnia 2021 roku. Korespondencja osobista].

51 Ibidem.

52 Nie jest ono uwzględnione np. w bazie danych UNESCO Index Translationum, brak go także w chronologii publikacji D.H. Lawrence’a opracowanej przez redaktorów wydania poświęconego recepcji D.H. Lawrence’a w Europie. Zob. D. Mehl, Ch. Jansohn, 2007: Timeline: European Reception of D. H. Lawrence. W: Ch. Jansohn, D. Mehl, eds.: The Reception of D. H. Lawrence in Europe. London, Continuum, s. xxxviii-xxxix. 
Dal' V., 1881: Tolkovyj slovar' živago velikoruskago âzyka. Tom' vtoroj. I-O. Sankt-Peterburg, Moskva, Sjemen.

De Grazia E., 1992: Girls Lean Back Everywhere. New York, Random House.

Dmitrienko G., 2019: Redefining Translation Spaces in the Soviet Union: From Revisionist Policies to a Conformist Translation Theory. „Traduction, terminologie, rédaction", t. 32, nr 1, s. 205-229.

Garcarz M., 2006: Wulgaryzmy a przekład, czyli życie wulgaryzmów od oryginału do przekładu. „Acta Universitatis Lodziensis. Linguistica Rossica”, nr 2, s. 159-173.

Glass L. D., 2006: Redeeming Value: Obscenity and Anglo-American Modernism. „Critical Inquiry”, t. 32, nr 2, s. 341-361.

Glass L. D., 2007: \#\$\%^\&*!?: Modernism and Dirty Words. „Modernism/Modernity", t. 14, nr 2, s. 209-223.

Gorâeva T., 2009: Političeskaâ cenzura v SSSR. 1917-1991 gg. Moskva, Rossijskaâ političeskaâ ènciklopediâ.

Grinčenko B. D., 1925: Slovar' ukrainskogo âzyka. Kiïv, Deržavne vidavnictvo Ukraïni.

Karpentêr A., 1989: „Kohanec' ledi Čatterlej”, per. z ìsp. „Vsesvit”, nr 8, s. 102.

Kuznecov S. A., 2000: Bol’šj tolkovyj slovar' russkogo âzyka. Sankt-Peterburg, "Norint".

Lawrence D. H., 1981: Lady Chatterley's Lover. London, Heinemann.

Leŝenko T., 1991: Dolgoe buduŝee: Vospominaniâ. Moskva, Sovetskij pisatel'.

Lorens D., 1932: Lûbovnik ledi Čatterlej. T. Leŝenko, per. Berlin, Petropolis.

Lourens D. G., 1989: Pornografiâ i nepristojnosti. Û. Komov, per. „Inostrannaâ literatura", nr 5, s. 232-236.

Lourens D. G., 1989-1990: Kohanec' ledi Čatterlej. S. Pavličko, per. „Vsesvit”, nr 12 (1989), s. 2-46; nr 1 (1990), s. 56-129; nr 2 (1990), s. 72-121.

Lourens D. G., 1990: Lûbovnik ledi Čatterli. I. Bagrov, M. Litvinova, per. „Inostrannaâ literatura”, nr 9, s. 5-72; nr 10, s. 58-125; nr 11, s. $128-$ 185.

Lourens D. G., 1999: Kohanec' Ledi Čatterlej. S. Pavličko, per. Kiïv, Osnovi.

Lourens D. G., 2011: Lûbovnik ledi Čatterli. I. Bagrov, M. Litvinova, per. Moskva, Èksmo.

Mehl D., Jansohn Ch., 2007: Timeline: European Reception of D. H. Lawrence. W: Ch. Jansohn, D. Mehl, eds.: The Reception of D. H. Lawrence in Europe. London, Continuum, s. xxi-xliii.

Mikitenko O., Gamalìj G., ukl., 2004: Žurnal inozemnoï literaturi „Vsesvit” u XX storičči (1925-2000): Bibliografičnij pokažčik zmistu. Kiïv, Vidavničij dìm „Vsesvit”.

Mirskij D., 1934: Intellidžentsia. Moskva, Sovetskaâ literatura. 
Możejko E., 1994: Modernizm literacki: niejasność terminu i dychotomia kierunku. „Teksty Drugie”, nr 5-6, s. 26-45.

Parkes A., 1996: Modernism and the Theatre of Censorship. New York, Oxford University Press.

Pease A., 2000: Modernism, Mass Culture, and the Aesthetics of Obscenity. Cambridge, Cambridge University Press.

Prohorov A. M., red., 1979: Sovetskij ènciklopedičeskij slovar'. Moskva, Sovetskaâ ènciklopediâ.

Reinhold N., 2007: Russian Culture and the Work of D. H. Lawrence: An Eighty-year Long Appropriation. W: Ch. Jansohn, D. Mehl, eds.: The Reception of D. H. Lawrence in Europe. London, Continuum, s. 187-197.

Riabczuk M., 2020: Re: Esej. [Wiadomość e-mail do: Andrij Saweneć, 3 kwietnia 2021 roku. Korespondencja osobista].

Rolph C. H., ed., 1961: The Trial of Lady Chatterley. London, Penguin Books.

Skudrzykowa A., Urban K., 2000: Mały słownik terminów z zakresu socjolingwistyki i pragmatyki językowej. Kraków, Towarzystwo Miłośników Języka Polskiego-Warszawa, Spółka Wydawniczo-Księgarska.

Solomon W., 2017: On Shock Therapy: Modernist Aesthetics and American Underground Film. „Screen Bodies”, t. 2, nr 1, s. 69-88.

Stapleton K., 2003: Gender and Swearing: A Community Practice. „Women and Language", t. 26, nr 2, s. 22-33.

Timofeev L. I., Turaev S. V., sost., 1974: Slovar' literaturovedčeskih terminov. Moskva, Prosveŝenie.

Toporov V., 2020: Zapretnyj plod slaŝe. W: Idem: O zapadnoj literature. [S.1.], „Izdatel'stvo K. Tublina”, s. 108-114.

Trudgill P., 2000: Sociolinguistics: An Introduction to Language and Society. 4 th ed. London, Penguin Books.

Veller M., 2007: NE Nožik NE Sereži NE Dovlatova. Moskva, Izdatel'stvo „AST”.

Volynskaâ A., 2017: Modernizm kak sovetskij antikanon: literaturnye debaty 1960-1970-h godov. „Logos”, t. 27, nr 6, s. 173-202.

Wardhaugh R., 2006: An Introduction to Sociolinguistics. 5th ed. [S.1.], Blackwell Publishing.

Witt S., 2013: Arts of Accommodation: The First All-Union Conference of Translators, Moscow, 1936, and the Ideologisation of Norms. W: L. Burnett, E. Lego, eds.: The Art of Accommodation. Literary Translation in Russia. Bern, Peter Lang AG, s. 141-184. 


\title{
Андрей Савенец
}

\section{Модернистская непристойность в переводе: украинский и русский переводы «Любовника леди Чаттерли» Д. Х. Лоуренса на закате СССР}

РЕЗЮМЕ | Статья посвящена переводам романа Д. Х. Лоуренса «Любовник леди Чаттерли» на украинский (С. Павлычко) и русский (И. Багров и М. Литвинова) языки, опубликованным в 1989-1990 гг. Анализ отталкивается от тезиса Лорена Гласса о значительной роли обсценной лексики в эстетике англо-американского модернизма XX века. Сравненительный анализ текстов переводов в этом аспекте продемонстрировал, что украинская переводчица сломала языковое табу, повторяя эстетический жест Лоуренса и бросая вызов устоявшимся традициям целевой литературной системы, в то время, как русские переводчики проявили более консервативный подход к передаче сексуальной лексики Лоуренса.

КЛЮЧЕВЫЕ СЛОВА | Д. Х. Лоуренс, модернизм, обсценная лексика, табу, перевод

\author{
Andrij Saweneć
}

\section{Modernist Obscenity in Translation: Ukrainian and Russian Translations of Lady Chatterley's Lover by D. H. Lawrence in the Late USSR}

SUMMARY | The paper focuses on two translations of Lady Chatterley's Lover by D. H. Lawrence into Ukrainian (by S. Pavlychko) and Russian (by I. Bagrov and M. Litvinova) published in 1989 and 1990. The framework for the analysis is provided by Loren Glass's idea of a significant role that obscene vocabulary played in the aesthetics of the twentieth-century Anglo-American literary modernism. The comparison of the two translations from this perspective shows significant differences in the translators' approaches: while the Ukrainian translator broke the language taboo repeating Lawrence's aesthetic gesture and challenging conventional traditions of the target literary system, the Russian translators presented a more conservative approach to rendering Lawrence's sexual-based language.

KEYWORDS | D. H. Lawrence, modernism, obscenity, taboo, translation

ANDRIJ SAWENEĆ | dr nauk humanistycznych, adiunkt w Katedrze Translatoryki i Języków Słowiańskich Katolickiego Uniwersytetu Lubelskiego Jana Pawła II; badacz przekładu i tłumacz. Jego zainteresowania naukowe skupiają się wokół kulturowych i społecznych aspektów przekładu artystycznego, teorii i praktyki przekładu poetyckiego oraz polsko-ukraińskich związków literackich. Opublikował m.in. monografię Poeziâ u perekladì „ukrä̈ns'ka” Šimbors'ka (2006). Przełożył na język ukraiński wybory wierszy Wisławy Szymborskiej (edycje dwujęzyczne): Versiâ podij / Wersja wydarzeń (2005) i Može, ce vse / Może to wszystko (2011), a także zbiór poezji Józefa Czechowicza Poema pro misto 
Lûblin / Poemat o mieście Lublinie (2005) i antologię poetycką Lûblin zdalâ, Lûblin zbliz'ka / Lublin z dala, Lublin z bliska (2017); z języka angielskiego na ukraiński przetłumaczył powieści Salmana Rushdiego i Ernesta Hemingwaya. Na język polski przetłumaczył z ukraińskiego i opublikował m.in. poemat Jurko Gudzia Barykady na Krzyżu (2014), zbiór felietonów Mykoły Riabczuka Poprzednie życie (2018) oraz wywiad rzekę Oresta Drula z Jurijem Andruchowyczem i Ołeksandrem Bojczenką Worochtarium (2019). Współredaktor Raportu o stanie kultury i NGO w Ukrainie (2012). Współredaktor serii wydawniczej Warsztatów Kultury w Lublinie pt. „Wschodni Express”. 